and affirming that Black and Native Americans surely support their armed struggle. Mead, who opined that the brigade would "totally bypass the left," summed up the feeling of resentment: "There's two kinds of people-there's those doing armed work, and they can take all the risks and make the sacrifices and we can sit back and criticize them... [W] e can just go about our work and revolution is some nebulous hope or passing fad" (200)

Burton-Rose's lack of criticism of this armed work limited the book's appeal for me. Although the author disapproves of some of the brigade's more boneheaded moves, he appears to only sympathize with left-wing critics who supported domestic armed struggle, like the Left Bank Collective or the Coven. The book reaches its nadir on this score in a chapter centred on an underground press article critical of the brigade. There, Burton-Rose records the criticisms of members and supporters of the brigade, bookended with his own critique of the article, which includes language and political arguments reminiscent of the circa1970s urban guerrillas he portrays.

I have to disagree with Burton-Rose. I do believe that it is easier to rob banks and bomb buildings than to change people's minds about capitalism and organize workers. And despite claims for the brigade's anti-vanguardism, I am convinced that this is endemic to urban guerrilla struggle, whether Leninist or not, as glimpsed at in the brigade's dismissal of much of the left and in statements like: "[N]o more mass meetings stalemating action" (179). But for all this criticism, the book is a must read for anyone with a critical eye who wants to change the world and avoid the dead ends of the past. As a communique by the brigade put it: "There are two things to remember about revolution: we are going to get our asses kicked, and we are going to win" (237)

Peter Graham

Queen's University

\title{
Barbara Foley, Wrestling with the Left: The Making of Ralph Ellison's Invisible Man (Durham: Duke University Press, 2010).
}

In August 1968, I took part in a bus drivers' strike at the Chicago Transit Authority, where I had a summer driving job. Picketing and rallies provided the chance to speak with drivers I had known only casually. One was a Black man, about fifty, who turned out to have been active in the great 1937 Flint sit-down that unionised General Motors. "I worked with the Socialists", he recalled. "Communists, too. I was pretty much in with them, until I realised they cared more about themselves than us".

My friend's comment reflects a collective intellectual shift by thousands of young Black workers and activists attracted to the Communist Party (CP) in the 
1930s. Barbara Foley's study of Ralph Ellison's Invisible Man, on the other hand, recognises no such shift or any reason for one. Foley presents the most benign version of the CP's behavior - its policies were largely correct except for its wartime subordination of Black and class struggle, a brief deviation corrected and "acknowledged" after criticism $(63-64,318)$. Foley portrays the party's healthy leftism by mentioning, for example, that Paul Robeson performed Soviet along with US folk songs, showing "the internationalism embedded in people's cultures everywhere" (81). Those aware of Stalin's repression of national minorities and Jews in the 1930s and 1940s will understand Robeson as politically naïve or willfully blind. Foley's naïveté in 2010 is another matter.

Given this view of the CP, Foley believes Invisible Man's anticommunism must represent not a turn in Black radical consciousness but a personal accommodation born of ambition and conformism. Her pursuit of this thesis has two parts, both archivally based: a study of Ellison's early writings and political development, and an analysis of Invisible Man's textual evolution.

Foley's account of Ellison's changing politics is flawed by an effort to separate an earlier Ellison critical of CP actions but still pro-Marxist from a later one whose "programmatic anticommunism" emerged "in the late 1940s, and not before" (17). This picture bifurcates a continuous intellectual development in order to show Ellison as jumping on the cold war bandwagon. To this end Foley avoids commenting on some early Ellison statements, such as a 1945 comment to Kenneth Burke that the CP's whole direction was wrong "since 1937", long before the wartime errors Foley recognises (64). She never mentions others, such as Ellison's 1945 words to Richard Wright in relation to the CP, "I would like very much to talk with you concerning independence of thought", which crystallize Ellison's growing sense of the party's hostility to such thought. ${ }^{1}$ And while considering Ellison a "cold warrior" (20), Foley ignores recent scholarship that finds his relation to liberal ideas more complex and critical than she assumes. ${ }^{2}$

The study of Ellison's drafts is valuable, if flawed. Foley reconstructs in plausible if partial detail the evolution of major episodes such as the eviction, the subway experience after Tod Clifton's murder, and the confrontation in which Brother Jack's glass eye pops out; transformations of some characters and omission of others; and the omission of whole text threads, notably one involving the journals of a young Marxist roomer at Mary Rambo's. These reconstructions show that early drafts were more Marxist, and also more naturalistic in method than Invisible Man's final text. "These unpublished materials", Foley says, " indicate the very different novel that Ellison might have written, indeed, started to write" (12). It is fair to say Foley wishes he had, in fact, written this novel: her discussion of the final text is unremittingly harsh, discounting it as a cold war tract.

While focusing on the novel's evolution away from Marxism, Foley fails to 
consider at all its evolution toward theorizing African Americans' position in the United States. Foley does not ask, for example, when Ellison introduced to the eviction scene the two-page catalogue of the Provos' possessions - emblematically representing African Americans' mixed identity — or, in the subway scene, the concluding Harlem street tableau indicating that this identity has depth and complexity the Brotherhood cannot see (240-45, 302-5). Foley's treatment of the protagonist's final meditation on his grandfather's dying words (338) never discusses Ellison's affirmation of the US "principle" and doesn't relate it to the strategic conception - central to African American history since Douglass - of using the US constitution as a weapon for struggle. Indeed, in a basic way, Invisible Man's quality as a representation of specifically African American experience is not very important to Foley.

Wrestling with the Left adds detail to our knowledge of Ellison's early period and of his novel's evolution. But its analysis of political contexts is naïve, its thesis that Invisible Man would have been a better work if it had remained more procommunist is implausible, and its failure to consider the novel's assessment of African American identity and history provides ironic if belated confirmation of my friend's assessment that "they cared more about themselves than us".

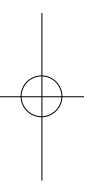

Christopher Z. Hobson SUNY College at Old Westbury

\section{NOTES}

1 Ralph Ellison, Letters to Richard Wright, 1937-1950. Richard Wright Papers. JWJ MSS 3, Box 97, Folder 1314, Beinecke Rare Book and Manuscript Library, Yale University.

${ }^{2}$ Examples include works by Meilí Steele, Danielle Allen, James Seaton (in Ralph Ellison and the Raft of Hope, ed. Lucas Morel, 2004), Jesse Wolfe (African American Review, 2000), myself (African American Review 2005), and others. Foley mentions some of these for specific points but never considers the authors' interpretive theses.

\section{Donna Jean Murch, Living for the City: Migration, Education, and the} Rise of the Black Panther Party in Oakland, California (Chapel Hill:

\section{University of North Carolina Press, 2010).}

Perhaps no Black organization has received more scholarly or popular attention over the past fifteen years than the Black Panther Party. Since Hugh Pearson's controversial work Shadow of a Panther (1994) there has been a steady stream of memoirs, and scholarly works on this iconic organization; some of which were written as correctives to Pearson's sensational text, while others were simply long awaited autobiographies and or academic monographs that sought to 